\title{
PENGARUH LITERASI EKONOMI DAN SELF CONTROL TERHADAP PERILAKU KONSUMTIF MAHASISWA FAKULTAS EKONOMI UNIVERSITAS NEGERI JAKARTA
}

\author{
Siti Nurjanah ${ }^{1}$, Saparudin Mukhtar $^{2}$, Elsi Ulfatmi $^{3}$, Nining Triningsih $^{4}$ \\ ${ }^{1-3}$ Dosen Universitas Negeri Jakarta \\ ${ }^{4}$ Guru SMAN 53 Jakarta \\ Email: saparuddin@feunj.ac.id
}

\begin{abstract}
This research was conducted at the Jakarta State University Economic Education Student. The method used in this research is the survey method and correlational approach. The purpose of this study was to determine the effect of economic literacy and self-control on the consumptive behavior of economics faculty students at Jakarta State University. The type of data used is primary data. The study population was all students of the faculty of economics at UNJ. The sampling technique of this research is the Simple Random Sampling method with a sample of 98 students. Data analysis in this study was carried out using multiple regression analysis. The coefficient of determination obtained by $27 \%$ of the consumer behavior variable as the dependent variable is determined by economic literacy and self-control as independent variations, while $73 \%$ of the consumer behavior variation is determined by other factors. The calculation results conclude there is an influence of economic literacy and self-control on the consumptive behavior of economics faculty students at Jakarta State University.
\end{abstract}

Keywords: Economic literacy, Self-control and consumptive behavior

\begin{abstract}
Abstrak
Penelitian ini dilakukan pada Mahasiswa Pendidikan Ekonomi Universitas Negeri Jakarta. Metode yang digunakan dalam penelitian adalah metode survey dan pendekatan korelasional. Tujuan dari penelitian ini adalah untuk mengetahui pengaruh literasi ekonomi dan self control terhadap perilaku konsumtif mahasiswa fakultas ekonomi di Universitas Negeri Jakarta. Jenis data yang digunanakan adalah data primer. Populasi penelitian adalah seluruh mahasiswa fakultas ekonomi UNJ. Teknik pengambilan sampel penelitian ini yaitu dengan metode Simple Random Sampling dengan sampel penelitian sejumlah 98 mahasiswa. Analisis data dalam penelitian ini dilakukan dengan menggunakan analisis regresi berganda. Koefisien determinasi yang diperoleh sebesar $27 \%$ variabel perilaku konsumtif sebagai variabel dependen ditentukan oleh literasi ekonomi dan self control sebagai variasi independen, sedangkan $73 \%$ variasi perilaku konsumtif ditentukan oleh faktor-faktor lainnya. Hasil perhitungan menyimpulkan terdapat pengaruh literasi ekonomi dan self control terhadap perilaku konsumtif mahasiswa fakultas ekonomi di Universitas Negeri Jakarta.
\end{abstract}

Kata kunci : Literasi ekonomi, Self control dan perilaku konsumtif

\section{PENDAHULUAN}

Dilihat dari sisi makro, tingkat konsumsi masyarakat yang tinggi merupakan hal positif karena dapat menopang pertumbuhan ekonomi, namun jika dilihat dari sisi mikro (perseorangan), konsumsi yang tinggi ini merupakan suatu permasalahan. Sebagaimana menurut Lubis (Sumartono, 2002 :117) Perilaku konsumtif adalah perilaku yang tidak lagi berdasarkan pada pertimbangan 
yang rasional, melainkan karena adanya keinginan yang sudah mencapai taraf yang sudah tidak rasional lagi. Berkonsumsi dalam hal ini tidak berdasarkan akan kebutuhan yang dimiliki terhadap suatu produk yang dibeli melainkan karena alasan-alasan lain seperti sekedar mengikuti arus mode, hanya ingin mencoba produk baru, ingin pengakuan sosial dan sebagainya.

Perkembangan zaman dan kemajuan teknologi yang tidak terelakkan juga menjadi pemicu seseorang untuk melakukan tindakan konsumtif, terutama di kota-kota besar salah satunya seperti di Jakarta. Mahasiswa merupakan salah satu kelompok yang rentan mengalami perubahan perilaku konsumtif. Hal ini dikarenakan pola konsumsi seseorang terbentuk pada usianya serta, mahasiswa termasuk kelompok yang mudah terbujuk rayuan iklan, ikut-ikutan teman, tidak realistis, dan cenderung boros dalam menggunakan uang. Dalam hal ini, pemahaman akan ilmu ekonomi sangat penting untuk membuat pertimbangan yang cerdas guna memuaskan kebutuhan secara bijak.

Menurut Sina (2012) prinsipnya literasi ekonomi merupakan alat yang berguna untuk merubah perilaku dari tidak cerdas menjadi cerdas. Ilmu ekonomi dapat dijadikan pedoman bagi mahasiswa dalam menentukan barang dan jasa yang akan dibeli. Mahasiswa juga dapat menetapkan skala prioritas dalam menentukan pilihan yang akan dikonsumsi. Secara umum individu yang paham akan ilmu ekonomi akan mampu untuk meminimalisir perilaku konsumtifnya sesuai dengan yang dibutuhkan sehingga tidak terjadi pemborosan dengan membeli barang yang tidak terlalu dibutuhkan.

Faktor lain yang berperan penting dalam mengendalikan perilaku konsumtif adalah adanya kontrol diri (Self Control). Kecenderungan seseorang yang lebih emosional saat melakukan konsumsi akan dapat berkurang jika mereka memiliki kontrol diri yang tinggi. Peningkatan terhadap kontrol diri maka akan disertai dengan penurunan perilaku konsumtif. Chaplin (2006) berpendapat bahwa kontrol diri yaitu kemampuan untuk membimbing tingkah laku sendiri dalam artian kemampuan seseorang untuk menekan atau merintangi impuls-impuls atau tingkah laku impulsif (Haryani \& Herwanto, 2015). 
Hal seperti ini juga terjadi dalam aktivitas ekonomi mahasiswa di Universitas Negeri Jakarta, dimana mahasiswa banyak terkena dampak akan kemajuan teknologi yang sedang berkembang pesat saat ini. Hampir 90\% mahasiswa adalah pengguna smartphone canggih yang bisa memanjakan diri mereka, baik dalam komunikasi maupun berkonsumsi. Selain itu tidak sedikit mahasiswa yang menghabiskan waktu luang dan mengerjakan tugas kelompok dengan nongkrong di cafe dan mall. Lokasi Universitas Negeri Jakarta sangat strategis, dekat dengan mall Arion dan Green Pramuka Square yang menyediakan berbagai produk, makanan serta hiburan, dimana mahasiswa dapat melakukan konsumsi tanpa batas.

\section{Perilaku Konsumtif}

Menurut (Raymond, 2001) mendefinisikan konsumtif sebagai perilaku konsumen yang memanfaatkan nilai uang lebih besar dari nilai produksi untuk barang dan jasa yang bukan menjadi kebutuhan pokok. Hal ini menandakan seseorang akan mengeluarkan uang tanpa berfikir barang tersebut sesuai dengan kebutuhannya. Menurut Sumartono (2002:117) mengatakan bahwa perilaku konsumtif dapat diartikan sebagai suatu tindakan menggunakan suatu produk secara tidak tuntas. Dari beberapa pendapat di atas dapat disimpulkan bahwa perilaku konsumtif adalah suatu tindakan individu dalam melakukan konsumsi secara berlebihan tanpa berfikir secara rasional dan lebih mementingkan keinginan daripada kebutuhan.

Menurut Sumartono (Sumartono, 2002) hal-hal yang mengindikasikan konsumen berperilaku berlebihan dalam melakukan konsumsi adalah sebagai berikut. (1) Membeli produk karena iming-iming hadiah. (2) Membeli produk karena kemasannya menarik. Membeli produk demi menjaga penampilan diri dan gengsi. (4) Membeli produk atas pertimbangan harga mahal dianggap prestige. (5) Membeli produk hanya sebagai simbol status. Memakai produk karena unsur komformitas terhadap model yang mengiklankan

\section{Literasi Ekonomi}

Menurut Pandey \& Bhattacharya (2012) melek ekonomi adalah kemampuan untuk menggunakan konsep ekonomi untuk membuat keputusan tentang penghasilan, tabungan, pengeluaran dan mengalokasikan uang. Sedangkan menurut Sina (dalam Kanserina:2015) literasi ekonomi 
merupakan alat yang berguna untuk merubah perilaku dari tidak cerdas menjadi cerdas, seperti bagaimana memanfaatkan pendapatan untuk menabung, berinvestasi, proteksi dan memenuhi kebutuhan hidup.

Menurut Wulandari (dalam Sina, 2012:137) literasi ekonomi adalah keterampilan hidup (life skill) yang harus dimiliki oleh siapa saja untuk membuat keputusan ekonomi yang tepat. beberapa pengertian literasi ekonomi di atas dapat disimpulkan bahwa literasi ekonomi adalah pemahaman yang berguna untuk dapat berfikir rasional dalam berperilaku menghasilkan keputusan yang tepat untuk dapat memenuhi kebutuhan. Maka dari itu penting bagi kita untuk dapat memahami lebih tantang ilmu ekonomi untuk tercapainya kehidupan yang sejahtera.

Berdasarkan penjelasan di atas dapat diambil kesimpulan indikator literasi sebagai berikut : Pemahaman tentang kebutuhan, kelangkaan, motif ekonomi, prinsip ekonomi, dan kegiatan ekonomi.

\section{Self Control}

Pakar psikologi kontrol diri, Lazarus (1976) menjelaskan bahwa kontrol diri menggambarkan keputusan individu melalui pertimbangan kognitif untuk mengontrol perilaku guna meningkatkan hasil dan tujuan tertentu, sebagaimana yang diinginkan. Wallston (dalam Sarafino,2006) menyatakan bahwa kontrol diri adalah perasaan individu bahwa ia mampu untuk membuat keputusan dan mengambil tindakan yang efektif untuk mendapatkan hasil yang diinginkan dan menghindari hasil yang tidak diinginkan. Sedangkan menurut Michele Borba (2008:96) mendefinisikan kontrol diri adalah mengendalikan pikiran dan tindakan agar dapat menahan dorongan dari dalam maupun dari luar sehingga dapat bertindak dengan benar. Disimpulkan bahwa kontrol diri adalah keputusan individu untuk mengambil tindakan yang efektif dalam menahan keinginan dan dorongan sesaat yang bertentangan dengan norma dan merugikan individu tersebut nantinya.

Berdasarkan konsep Averill 1973 (dalam Thalib, 2010:110) kontrol diri menjadi 3 aspek yaitu : (1) Mengontrol perilaku, (2) Mengontrol Kognitif dan (3) Mengontrol Keputusan.

\section{METODE PENELITIAN}

Metode penelitian yang digunakan dalam penelitian ini adalah metode pendekatan kuantitatif, metode survey 
dan dengan menggunakan analisis regresi berganda. Populasi dalam penelitian ini adalah seluruh mahasiswa fakultas ekonomi tahun ajaran 2017/2018 yang berjumlah 3.341 mahasiswa. Metode pemilihan sampel digunakan adalah metode Simple Random Sampling, jumlah sampel yang diambil pada mahasiswa Fakultas Ekonomi di Universitas Negeri Jakarta untuk diteliti adalah sebagai berikut:

$$
\begin{array}{r}
n=\frac{3.341}{1+3.341(0,1)^{2}}=\frac{3.341}{34,41} \\
=97,09 \text { atau } 98
\end{array}
$$

Berdasarkan perhitungan rumus slovin di atas, jumlah sampel mahasiswa yang diambil sebanyak 98 responden.

\section{HASIL DAN PEMBAHASAN}

\section{Uji Normalitas}

Uji normalitas dengan One Sample Kolmogorov-Smirnov Test dapat diketahui nilai Asympt. Sig (2-tailed) variabel perilaku konsumtif (Y) bernilai 0, 633 maka sesuai dengan ketentuan $0,633>0,05$ maka nilai residual tersebut adalah normal dan $\mathrm{H}_{\mathrm{o}}$ diterima. Untuk variabel Literasi Ekonomi $\left(\mathrm{X}_{1}\right)$ bernilai
0,230, maka sesuai dengan ketentuan $0,230>0,05$ maka nilai residual tersebut adalah normal dan $\mathrm{H}_{\mathrm{o}}$ diterima. Dan untuk variabel Self Control $\left(\mathrm{X}_{2}\right)$ bernilai 0,210, maka sesuai dengan ketentuan $0,210>0,05$ maka nilai residual tersebut adalah normal dan $\mathrm{H}_{\mathrm{o}}$ diterima.

\section{Uji Linearitas}

Nilai linearitas literasi ekonomi dan self control terhadap perilaku konsumtif adalah 0,117 dan 0,418 dimana nilai tersebut lebih dari taraf signifikan sebesar 0,05. Maka disimpulkan bahwa Ha diterima dan Ho ditolak.

\section{Uji Multikolinearitas}

Nilai Tolerance dari literasi ekonomi dan self control adalah 1,000 yang berarti > dari 0,1 dan VIF sebesar 1,000 yang berarti < dari 10. Dapat disimpulkan bahwa model regresi tidak terdapat masalah multikolinearitas.

\section{Uji Heterokedastisitas}

Untuk mendeteksi ada atau tidaknya heteroskedastisitas dapat dilkukan dengan melihat pola titik-titik pada Scatterplots regresi. 


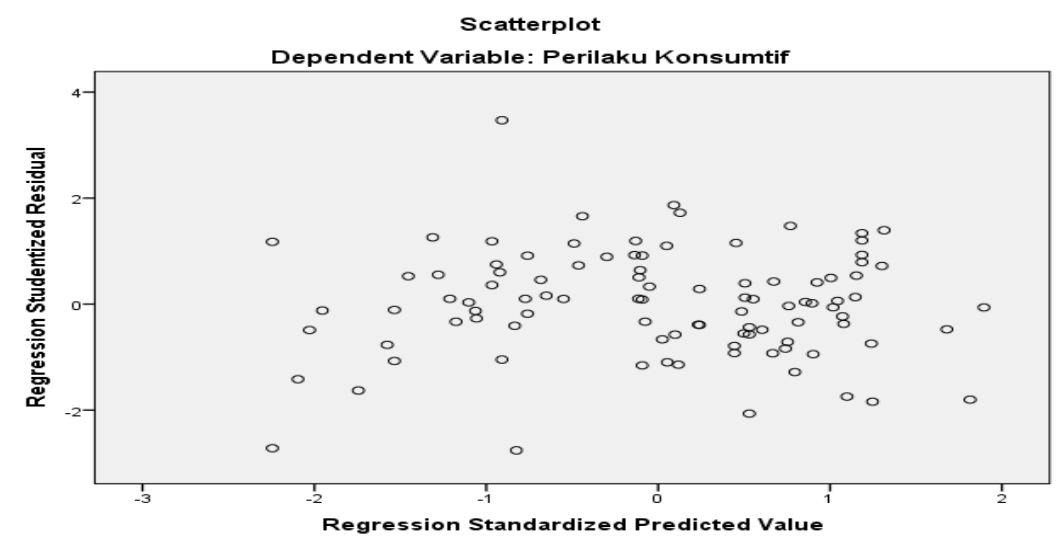

Diagram 1. Uji Heterokedastisitas

Berdasarkan hasil gambar di atas diketahui bahwa titik-titik menyebar secara acak baik diatas maupun dibawah angka 0 pada sumbu $Y$. Hal ini menunjukkan tidak terjadi heterokedastisitas pada model regresi ini.

\section{Analisis Regresi Berganda}

Untuk melihat seberapa pengaruh masing-masing variabel bebas dan terikat, akan terlihat pada analisis regresi

berganda.

Tabel 1. Hasil Analisis Regresi Berganda

\begin{tabular}{|c|c|c|c|c|c|c|}
\hline \multicolumn{7}{|c|}{ Coefficients $^{\mathbf{a}}$} \\
\hline \multirow{2}{*}{\multicolumn{2}{|c|}{ Model }} & \multicolumn{2}{|c|}{ Unstandardized Coefficients } & \multirow{2}{*}{$\begin{array}{c}\begin{array}{c}\text { Standardized } \\
\text { Coefficients }\end{array} \\
\text { Beta } \\
\end{array}$} & \multirow[t]{2}{*}{$\mathrm{T}$} & \multirow[t]{2}{*}{ Sig. } \\
\hline & & $\mathrm{B}$ & Std. Error & & & \\
\hline \multirow[t]{3}{*}{1} & (Constant) & 108.646 & 7.089 & & 15.327 & .000 \\
\hline & $\begin{array}{l}\text { Literasi } \\
\text { Ekonomi }\end{array}$ & -.648 & .151 & -.375 & -4.301 & .000 \\
\hline & Self Control & -.339 & .080 & -.370 & -4.243 & .000 \\
\hline
\end{tabular}

Berdasarkan tabel koefisien dapat diketahui bentuk persamaan regresi berganda.

$$
\hat{Y}=108.646-0,648 X_{1}-0,339 X_{2}
$$

Model analisis regresi berganda tersebut dapat menjelaskan bahwa, apabila literasi ekonomi mengalami penurunan satu skor maka perilaku konsumtif akan berkurang sebesar 0,648. Nilai kofisien $\beta_{2}$ sebesar $-0,339$ yang bernilai negatif, artinya jika self control mengalami peningkatan dan literasi ekonomi tetap maka perilaku konsumtif akan menurun sebesar 0,339. Uji t

Hasil perhitungan uji $t$

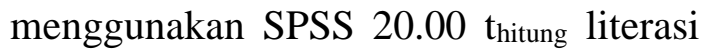
ekonomi sebesar $\quad-4,301$ dan $t_{\text {tabel }}$ sebesar 1,985. Nilai thitung sebesar 3,468> $\mathrm{t}_{\text {tabel }}$ sebesar 1,985. Jadi dapat 
disimpulkan secara parsial terdapat pengaruh negatif dan signifikan antara literasi ekonomi dengan perilaku konsumtif. Sedangkan self control nilai $t_{\text {hitung }}$ sebesar -4,243 $>t_{\text {tabel }}$ sebesar 1,985. Jadi dapat disimpulkan secara parsial terdapat pengaruh negatif dan signifikan antara self control dengan perilaku konsumtif.

\section{Uji F}

Berdasarkan hasil perhitungan uji $\mathrm{F}$ dengan SPSS 20.0 $\mathrm{F}_{\text {hitung }}$ sebesar 18,325 dan $F_{\text {tabel }}$ sebesar 3,09. Dapat diketahui F dengan demikian dapat disimpulkan bahwa literasi ekonomi dan self control secara bersama-sama berpengaruh terhadap perilaku konsumtif.

\section{Uji Koefisien Determinasi ( $\mathbf{R}^{\mathbf{2}}$ )}

Berdasarkan data hasil perhitungan uji koefisien determinasi, diketahui bahwa angka R square sebesar 0,278. Hal ini berarti $27 \%$ perubahan variabel Y disebabkan oleh perubahan faktor variabel X1 (Literasi Ekonomi) dan X2 (Self Control), sedangkan sisanya $73 \%$ disebabkan faktor lain yang tidak diteliti.

\section{Pengaruh Literasi Ekonomi terhadap Perilaku Konsumtif}

Nilai $t_{\text {hitung }}$ dari literasi sebesar 3,468> $t_{\text {tabel }}$ sebesar 1,985 ( $t_{\text {hitung }}>t_{\text {tabel }}$ ), yang artinya literasi ekonomi secara parsial berpengaruh negatif dan signifikan terhadap perilaku konsumtif mahasiswa. Penelitian ini juga semakin memperkuat teori-teori sebelumnya yang menyatakan bahwa pengaruh antara literasi ekonomi dengan perilaku konsumtif mahasiswa.

Seperti yang yang dinyatakan oleh Budiwaty dalam Dias Kanserina, bahwa "rendahnya tingkat literasi ekonomi seseorang akan berdampak pada sikap konsumtif para konsumen". Seseorang yang memiliki literasi yang rendah cenderung lebih mengutamakan keinginannya dibandingkan kebutuhannya karena bertindak tidak berfikir secara rasional. Penelitian ini juga diperkuat dengan penelitian sebelumnya yang dilakukan oleh Dias Kanserina dengan judul "Pengaruh Literasi Ekonomi dan Gaya Hidup Terhadap Perilaku Konsumtif Mahasiswa Jurusan Pendidikan Ekonomi UNDIKSHA 2015". Hasil penelitian ini menunjukkan literasi ekonomi (X1) berpengaruh negatif terhadap perilaku konsumtif (Y) Mahasiswa Jurusan Pendidikan Ekonomi UNDIKSHA 2015 sebesar -2,470 (Kanserina, 2015).

2. Pengaruh Self Control terhadap Perilaku Konsumtif 
Nilai $t_{\text {hitung }}-4,243>t_{\text {tabel }} 1,985$ yang berarti bahwa self control secara parsial berpengaruh negatif dan signifikan terhadap perilaku konsumtif. Hasil penelitian ini sesuai dengan penelitian terdahulu yang dilakukan oleh Nurita Dewi, Rusdarti, St. Sunarto (2017: 29-35) dengan judul "Pengaruh Lingkungan Keluarga,Teman Sebaya, Pengendalian Diri dan Literasi Keuangan terhadap Perilaku Konsumtif Mahasiswa". Hasil penelitian menunjukkan bahwa pengendalian diri berpengaruh negatif sebesar 16,1\% terhadap perilaku konsumtif

Dengan demikian dari teori diatas dapat disimpulkan bahwa self control dapat mempengaruhi seseorang dalam hal melakukan perilaku konsumtif, karena dengan adanya self control yang negatif maka akan cenderung untuk berperilaku kearah pemborosan.

\section{Pengaruh Literasi Ekonomi dan}

Self Control terhadap Perilaku

\section{Konsumtif}

Berdasarkan perhitungan melalui uji $F$ diperoleh nilai $F_{\text {hitung }}$ sebesar 18,325 yang lebih besar dari $\mathrm{F}_{\text {tabel }}$ yang sudah ditentukan 3,09. Sehingga dapat disimpulkan bahwa literasi ekonomi dan self control secara simultan (serentak) berpengaruh terhadap perilaku konsumtif.

Persentase sumbangan pengaruh literasi ekonomi dan self control terhadap perilaku konsumtif dibuktikan dengan diperolehnya koefisien determinasi dengan melihat $\mathrm{R}$ square $\left(\mathrm{R}^{2}\right)$ sebesar 0,278 yang berarti bahwa pengaruh variabel independen (literasi ekonomi dan self control) terhadap variabel dependen (perilaku konsumtif) sebesar 27,8\%, sedangkan sisanya sebesar $72,2 \%$ dipengaruhi oleh faktor lain atau variabel lain yang tidak diteliti.

\section{PENUTUP}

Berdasarkan hasil dari penelitian mengenai pengaruh literasi ekonomi dan self control terhadap perilaku konsumtif mahasiswa Fakultas Ekonomi di Universitas Negeri Jakarta, maka dapat disimpulkan sebagai berikut:

1. Terdapat pengaruh negatif dan signifikan antara literasi ekonomi terhadap perilaku konsumtif mahasiswa yaitu sebesar -0,315. Artinya semakin rendah tingkat pengetahuan dan pemahaman siswa mengenai literasi ekonomi akan semakin tinggi tingkat perilaku konsumtif mahasiswa, begitu pun sebaliknya. 
2. Terdapat pengaruh positif dan signifikan antara variabel self control terhadap perilaku konsumtif mahasiswa yaitu sebesar 0,327. Artinya semakin tinggi self control maka akan semakin rendah tingkat perilaku konsumtif mahasiswa, sebaliknya jika self control rendah maka akan meningkat perilaku konsumtif mahasiswa.

3. Literasi Ekonomi (X1) dan Self Control (X2) memiliki sumbangsih langsung dan signifikan terhadap Perilaku Konsumtif (Y) yaitu sebesar 0,245 sedangkan sisanya 0,229 dipengaruhi oleh faktor lain yang tidak diteliti. Dengan demikian, terdapat pengaruh positif dan simultan (serentak) antara literasi ekonomi dan self control terhadap perilaku konsumtif. Artinya semakin tinggi tingkat literasi ekonomi mahasiswa dan self control dapat mengurangi perilaku konsumtif.

\section{DAFTAR PUSTAKA}

Borba, M. (2008). Membangun Kecerdasan Moral. Jakarta: PT. Gramedia Pustaka Utama
Haryani, I., \& Herwanto, J. (2015).

Hubungan Konformitas dan

Kontrol Diri Dengan Perilaku

Konsumtif Terhadap Produk

Kosmetik pada Mahasiswi. 5-11

Kanserina, D. (2015). Pengaruh Literasi

Ekonomi Dan Gaya Hidup

Terhadap Perilaku Konsumtif

Mahasiswa Jurusan Pendidikan

Ekonomi Undiksha 2015. (1), 1-11

Lazarus, R. S.(1976). Emotional and

Adaptation. New York : Mc Graw-

Hill Publishing Company

Pandey, Chancala \& Bhattacharya.

(2012). Economic Literacy of

Senior Secondary School Teacher:

A Field Study. Jurnal of All India Association for Education Research. Volume 24 No. 1

Sarafino, E. P. (2006). Health Pschology

: Biopsychosocial Interaction.

Fiveth Edition. New York: John

Wiley \&Sons, Inc

Sina, Peter Garlans. (2012). Analisis Literasi Ekonomi. Salatiga : Alumni Magister Manajemen UKSW

St.Sunarto, Nurita Dewi dan Rusdarti.

(2017). Pengaruh Lingkungan Keluarga, Teman Sebaya, Pengendalian Diri dan Literasi Keuangan terhadap Perilaku 
Jurnal Parameter Volume 31 No. 2 DOI : doi.org/10.21009/parameter.312.05

P-ISSN : 0216-261X E-ISSN : 2620-9519

Konsumtif Mahasiswa. Journal of Economic Education. Vol.6 No.1. 29-35

Sumartono. (2002). Terperangkap dalam Iklan: Meneropong Imbas Pesan Iklan Televisi. Bandung: Alfabeta
Thalib, S.B. (2010). Psikologi Pendidikan Berbasis Analisis Empiris Aplikatif. Jakarta: Kencana Media Grup 